\title{
Bmi-I expression predicts prognosis in squamous cell carcinoma of the tongue
}

\section{Häyry',2, LK Mäkinen', T Atula', H Sariola ${ }^{2}$, A Mäkitie', I Leivo ${ }^{3}$, H Keski-Säntti', J Lundin ${ }^{4}$, C Haglund ${ }^{5,7}$ and J Hagström ${ }^{*, 3,6,7}$}

'Department of Otolaryngology and Head and Neck Surgery, Helsinki University Central Hospital, PO Box 220, Haartmaninkatu 4E, Helsinki 00290 HUS, Finland; '2Department of Developmental Biology, Institute of Biomedicine, University of Helsinki, PO Box 63, Haartmaninkatu 8, Helsinki 000 I4, Finland; ${ }^{3}$ Department of Pathology, Haartman Institute, University of Helsinki, PO Box 21, Haartmaninkatu 3, Helsinki 000 I4, Finland; ${ }^{4}$ Department of Oncology, Helsinki University Central Hospital, PO Box 180, Haartmaninkatu 4, Helsinki 00290 HUS, Finland; ${ }^{5}$ Department of General Surgery, Helsinki University Central Hospital, PO Box 340, Haartmaninkatu 4, Helsinki 00290 HUS, Finland; ' Department of Oral Pathology, Institute of Dentistry, University of Helsinki, PO Box 4I, Mannerheimintie 172, Helsinki 00014 , Finland

BACKGROUND: The prognosis of squamous cell carcinoma of the oral tongue is poor and it would be beneficial to find prognostic markers to better adjust treatment. Bmi-I controls cell cycle and self-renewal of tissue stem cells, transcription factor c-myc affects cell proliferation and apoptosis, and Snail regulates epithelial-mesenchymal transition. The expression of these markers has been connected to prognosis in many cancer types.

METHODS: Bmi- I, c-myc, and Snail expressions were studied in our material consisting of 73 primarily TI NOMO oral tongue carcinoma patients. We compared the immunoexpressions of Bmil, c-myc, and Snail with clinical parameters including the degree of histological differentiation, tumour size, TNM classification, depth of invasion, and resection margins. In addition, survival analyses were performed, comparing disease-free survival time with the registered protein expression of the markers mentioned above. RESULTS: A significant correlation between Bmi-I protein expression and recurrence (log-rank test, $P=0.005$ ) was detected. Snail and c-myc expression did not correlate with prognosis. Snail expression correlated with histopathological grade (Fisher's exact test, $P=0.007)$ and with the invasion depth of tumours $\left(\chi^{2}\right.$-test, $\left.P=0.037\right)$.

CONCLUSION: Negative Bmi-I immunoexpression might serve as a marker of poor prognosis in oral tongue carcinoma patients. British Journal of Cancer (2010) I 02, 892-897. doi:I0.1038/sj.bjc.6605544 www.bjcancer.com

Published online 9 February 2010

(C) 2010 Cancer Research UK

Keywords: Bmi-I; c-myc; Snail; oral cancer; prognosis; immunohistochemistry

Squamous cell carcinoma (SCC) is the most common malignancy of the upper aerodigestive tract (Barnes et al, 2005). Dissemination of SCC through lymphatic routes may occur in the early course of the disease. Presence of lymph node metastasis is considered the most important tumour-related adverse prognostic factor in head and neck SCC (Ferlito et al, 2002a, b; Howell and Grandis, 2005). In individual patients, the TNM classification does not reliably predict clinical outcome; even small T1 oral SCCs (OSCC) may have occult nodal metastasis and may potentially behave aggressively (Keski-Säntti et al, 2007). Identifying these patients is important for optimal treatment planning. In many studies, the histological grade of OSCC is found to be non-predictive, although some studies claim the opposite (Al-Rajhi et al, 2000; Keski-Säntti et al, 2007; Silveira et al, 2007; Arduino et al, 2008). It seems that the most important histopathological predictor of nodal metastasis and poor survival is the depth of tumour infiltration (Woolgar, 2006). It has been suggested, however, that the value of depth of infiltration in clinical decision making is limited because of poor

*Correspondence: Dr J Hagström; E-mail: jaana.hagstrom@hus.fi

${ }^{7}$ These authors contributed equally to this work

Received 15 July 2009; revised I4 December 2009; accepted 17

December 2009; published online 9 February 2010 specificity in identifying high-risk patients (Keski-Säntti et al, 2007).

Bmi-1 is an essential constituent of the polycomb repressive complex 1, a key epigenetic regulator. Through chromatin and histone modifications (for example, methylation), it controls the cell cycle and self-renewal of tissue stem cells (Spivakov and Fisher, 2007). Bmi-1 can influence the central tumour suppressors $\mathrm{Rb}$ and $\mathrm{p} 53$ by suppressing the $16^{\text {Ink4a }} / \mathrm{p} 19^{\text {Arf }}$ locus (Molofsky et al, 2005). Bmi-1 is overexpressed in OSCC cells when compared with normal mucosa and is thought to influence cell proliferation and survival in oral carcinogenesis (Kang et al, 2007). Overexpression of Bmi-1 is found to correlate with poor prognosis in the non-keratinising type of nasopharyngeal carcinoma, breast, and hepatocellular carcinoma, as well as in nervous system tumours such as oligodendrogliomas and medulloblastomas, and correlation with tumour stage has been reported in non-small-cell lung cancer (Kim et al, 2004; Leung et al, 2004; Song et al, 2006; Häyry et al, 2008; Vrzalikova et al, 2008; Wang et al, 2008).

The c-myc proto-oncogene was first detected in Burkitt's lymphoma, but has later been connected to many other cancers, including breast and colon carcinomas, neuroblastomas, osteosarcomas, and melanomas (Pelengaris et al, 2002). C-myc is a transcription factor that activates many other genes and effects, for example, cell proliferation and apoptosis. Both Bmi-1 and 
c-myc are capable of immortalising certain cells in vitro and these factors converge on the same pathways as c-myc signalling can influence Bmi-1 activity and vice versa (Jacobs et al, 1999; Dimri et al, 2002; Gil et al, 2005; Guney et al, 2006). C-myc is also assumed to participate in oral carcinogenesis, and downregulation of c-myc mRNA has even been associated with poor prognosis (Vora et al, 2007; Koehn et al, 2008).

Snail is a zinc-finger transcription factor essential for epithelialmesenchymal transition because it downregulates the expression of cell adhesion and basement membrane proteins, most importantly cadherins (Batlle et al, 2000). Thus, cells gain a fibroblast-like phenotype capable of migration and also enhanced invasiveness, as has been shown in SCC cells (Takkunen et al, 2006, 2008). In OSCC, the loss of cell adhesion molecules (for example, E-cadherin and $\beta$-catenin), the downregulation of which is linked to Snail expression, has been associated with tumour differentiation (Zidar et al, 2008). In OSCC, Snail immunopositivity has been detected predominantly only in the invasive front, and the overall expression has been very low (Zidar et al, 2008). However, no association with metastases has been observed (Mahomed et al, 2007), even though in another epithelial carcinoma, oesophageal SCC, Snail expression in the invasive tumour front seems to correlate with lymph node metastases, as well as with clinicopathological tumour stage (Usami et al, 2008).

With regard to the management of OSCC, it would be remarkably advantageous to find prognostic markers that better predict clinical outcome. For this study, we selected early-stage oral tongue SCCs (T1N0M0 and T2N0M0) that were all treated with curative intent in a fairly uniform manner (Keski-Säntti et al, 2006). Immunoexpression of Snail, Bmi-1, c-myc, and Ki-67 in oral tongue carcinoma tissue array blocks was studied and compared with clinical outcome.

\section{MATERIALS AND METHODS}

\section{Patients}

Patient characteristics were the same as described by Keski-Säntti et al $(2006,2007)$. In summary, clinicopathological data of 141 patients diagnosed with SCC of the oral tongue at the Helsinki University Central Hospital between 1992 and 2002 were reviewed. Only patients with tumours clinically defined as T1/T2N0, original histopathological material available for review, and clinical follow-up data of a minimum of 24 months or until death were included in the study. The dates and causes of death were provided by Statistics Finland, the national agency of population statistics. A total of 73 patients were eligible for inclusion (36 men and 37 women, median age 59 years, range 23-95 years). Of the tumours, $35(48 \%)$ had been clinically classified as T1 and $38(52 \%)$ as T2. All patients had undergone resection of the primary tumour. In 31 patients, there had been no further treatment primarily. A total of 42 patients underwent elective neck treatment (neck dissection: $n=9$; neck dissection + radiotherapy: $n=32$; radiotherapy: $n=1$ ). All patients were treated with curative intent.

The original histological sections of each patient were re-assessed and tumour grade and depth of invasion were determined by a single experienced head and neck pathologist (IL).

\section{Tissue array blocks}

For tissue microarray blocks, we selected three different areas in two sets from normal haematoxyllin - eosin blocks from each patient to be detached with a $1 \mathrm{~mm}$ punch and placed into a paraffin block with a tissue manual microarrayer (BeecherInstruments Inc, Silver Spring, MD, USA). The first area was selected close to the surface epithelium, the next in the middle of the tumour, and the last at the invading front. Two parallel tissue array blocks were produced for immunostainings. In eight patients, all array spots were missing or included no tumour tissue. In these non-representative cases, we accomplished the study by staining sections from whole tumour blocks in five cases, but representative tissue was lacking for three cases.

\section{Immunohistochemistry}

Tissue microarray-block slides and tissue slides were cut into $4 \mu \mathrm{m}$-thick sections, deparaffinised in xylene, rehydrated through graded alcohol series, and treated in a PT-module (LabVision UK Ltd, Runcorn, UK) in Tris- $\mathrm{HCl}$ buffer ( $\mathrm{pH} \mathrm{8.5)} \mathrm{for} 20 \mathrm{~min}$ at $98^{\circ} \mathrm{C}$ and with $0.3 \%$ Dako REAL peroxidase-blocking solution (DakoCytomation, Glostrup, Denmark) for $5 \mathrm{~min}$ to block endogenous peroxidase. Immunostaining was performed by adding mouse monoclonal c-myc (9E10) antibody (Santa Cruz, Santa Cruz, CA, USA, diluted 1:400 in Dako REAL antibody diluent, Biohit, Helsinki, Finland); or mouse monoclonal Bmi-1 (ab 14389) (Abcam, Cambridge, UK, 1:400); or rabbit polyclonal Snail (ab17731) (Abcam, 1:2000); or monoclonal mouse Ki-67 Antigen (DakoCytomation, $1: 100$ ) for $1 \mathrm{~h}$, followed by a $30 \mathrm{~min}$ incubation with the Dako REAL EnVision/HRP detection system. Rabbit/ mouse (ENV) reagent slides were finally visualised using Dako REAL DAB + chromogen for 10 min. Between each step, slides were washed with PBS-0.04\% Tween 20. Slides were counterstained with Meyer's haematoxylin and mounted in mounting medium (Aquamount, BDH, Poole, UK). In every immunohistochemical staining batch, we used a specific positive control for every antibody used. As a negative control, specimens diluted without a primary antibody were used. As negative/positive controls, we used reactive lymph node tissue, showing a negative and a positive Bmi staining pattern (Raaphorst et al 2000; Dutton et al 2007) (not shown). As a positive control for c-myc and Snail immunohistochemistry, breast and ovarian carcinoma tissue samples were used (not shown).

\section{Evaluation of immunostainings}

Immunostainings were evaluated by two independent pathologists (JH and HS) without knowledge of clinical data. The percentage of positive tumour cells was evaluated. No positivity was graded as 0 , up to $30 \%$ positive cells were graded as 1 (very low), $30-50 \%$ as 2 (low), $50-80 \%$ as 3 (moderate), and over $80 \%$ as 4 (high). Evaluation was carried out according to Buduneli et al (2007). Bmi-1 and Snail positivity was nuclear and c-myc scoring was carried out as both nuclear and cytoplasmic. Each patient was expected to have six spots, and for each patient we selected the highest immunoscore for further analysis.

\section{Statistical analysis}

For categorical, non-ordered variables, cross tabulations were analysed using the $\chi^{2}$-test, or when the $\chi^{2}$-test was not valid, Fisher's exact test was used. All $P$-values are two-sided and exact. In survival analysis, an event was defined as evidence of disease in any form, including local recurrence, neck metastasis, distant metastasis, or death of the primary disease verified in autopsy.

Follow-up time was calculated from the date of first treatment (surgery) until event, and patients alive and disease free or deceased from non-tumour-related causes were censored on the last date of follow-up. Kaplan-Meier curves were plotted from follow-up data and the log-rank test was used to compare outcome between patient categories. The Cox multivariate regression analysis was used to control for confounding factors. SPSS version 15.0 software (SPSS, Chicago, IL, USA) was used. 


\section{RESULTS}

\section{Bmi-1, c-myc, and Snail protein expression}

Bmi-1 protein expression was detected in $82 \%$, nuclear c-myc expression in $63 \%$, cytoplasmic c-myc expression in $73 \%$, and Snail expression in $100 \%$ of all tumours. Bmi-1 expression, when present, ranged from very low to high frequency of immunoreactive cells. Nuclear c-myc expression was usually observed at a low frequency, in less than $50 \%$ of tumour cells. In only two cases was high frequency of nuclear c-myc expression found $(>50 \%)$. Snail expression was observed in all samples, with the majority of tumour cells being immunoreactive. However, regarding Snail expression, two groups of patients could be distinguished, one with less than $80 \%$ immunoreactive cells and another in which virtually all tumour cells expressed Snail protein $(>80 \%)$. The different levels of protein expression are summarised in Table 1 and examples of different patterns of protein expression are shown in Figures 1 and 2.

\section{Bmi-1 protein expression is a prognostic marker}

In a Kaplan-Meier survival analysis, a correlation between Bmi-1 protein expression and recurrence (log-rank test, $P=0.005$ ) was

Table I Expression of Bmi-I, C-myc, Snail, and Ki-67 in squamous cell carcinoma of the tongue

\begin{tabular}{lcccccc}
\hline & \multicolumn{5}{c}{ Number of cases } \\
\cline { 2 - 7 } $\begin{array}{l}\text { Immunoexpression } \\
\text { scoring }\end{array}$ & None & Very low & Low & Moderate & High & Total \\
\hline Bmi-I & 13 & 25 & 17 & 10 & 5 & 70 \\
C-myc(n) & 27 & 35 & 6 & 2 & 0 & 70 \\
C-myc(cp) & 20 & 25 & 10 & 11 & 4 & 70 \\
Snail & 0 & 0 & 4 & 18 & 47 & $69^{\text {a }}$ \\
Ki-67 & 0 & 13 & 24 & 14 & 16 & $67^{\text {a }}$ \\
\hline
\end{tabular}

Abbreviations: C-myc(n) = nuclear staining; C-myc(cp) = cytoplasmic staining. ${ }^{\mathrm{a}}$ For these markers, $<70$ representative samples were available. The frequency of immunopositive tumour cells is shown. Bmi-I and Snail expression is nuclear, C-myc expression is presented separately for nuclear and cytoplasmic immunoreactivity. No immunoreactive cells is scored as none, those with $<30 \%$ positive cells as very low those with 30-50\% as low, 5I-80\% moderate, and those with over $80 \%$ immunoreactive tumour cells are scored as high. detected (Figure 3). The absence of Bmi-1 protein in the tumour cells was associated with a higher risk of recurrence. During the follow-up time of this study, only three patients died of OSCC. It is noteworthy that all three deaths occurred in Bmi-1-negative cases. The majority of patients remained disease free during follow-up. Therefore, the primary end point for survival analyses was defined as recurrence of disease. For statistical analysis, cases were grouped into three categories: Bmi-1 negative, low, and a high proportion of positive immunoreactive tumour cells. The mean disease-free time for Bmi-1-negative cases was 53 months (95\% CI 29-77 months), whereas patients with tumours with a high frequency of Bmi-1-expressing cells had a mean disease-free time of 112 months (95\% CI 97-126 months).

To rule out confounding factors, a multivariate analysis was also performed. In this, the depth of invasion, tumour size, margin of surgical resection, and $\mathrm{T}$ classification were included, along with the Bmi-1 protein expression score. In the Cox regression model, Bmi-1 expression remained the only independent covariate $(P=0.012)$. The other factors were not statistically significant. The hazard ratio between absent Bmi-1 expression and high Bmi-1 expression was 5.2 (95\% CI 1.5-18.3).

Although treatment of the neck does not directly reflect patient or tumour characteristics, we also analysed the prognostic impact of Bmi-1 expression with regard to the performed treatment. When patients who received an elective neck treatment and those without any elective neck treatment (observation only) were analysed independently, Bmi-1 expression was prognostic only in the group of patients in whom neck treatment was performed (log-rank test, $P=0.004$ ). However, the group of patients who did not receive neck treatment is smaller ( 28 cases analysed) than the group of patients who received elective neck treatment (42 cases); therefore, this lack of statistical significance is probably due to the small sample size. This is also the case when analysing disease-free survival times separately for recurrences in lymph nodes. Only 16 cases presented lymph node recurrence, and therefore a reliable statistical analysis is not possible.

\section{Prognostic significance of c-myc, Snail, and ki-67 protein expression}

Survival analyses for the expression of c-myc, Snail, and Ki-67 were performed in an identical manner as that for Bmi-1, with tumour recurrence as the primary end point. For Snail, tumours were first grouped into two categories: high $(>80 \%)$ and moderate $(<80 \%)$ frequency of immunoreactive tumour cells.

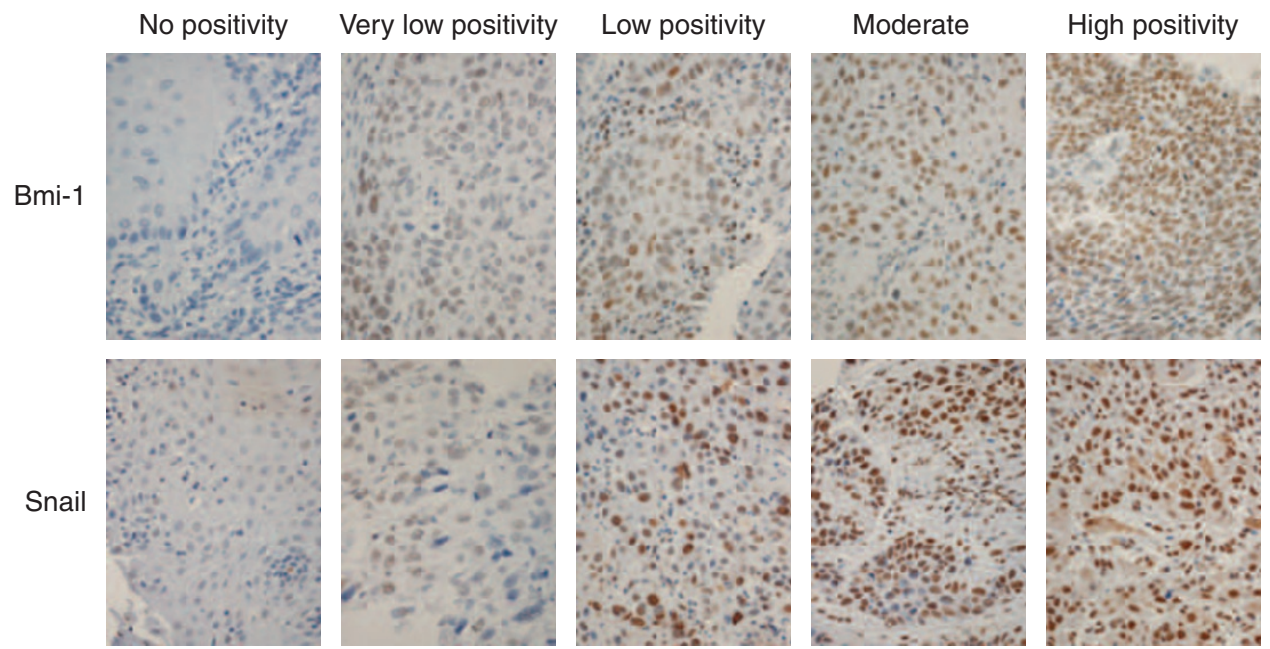

Figure I Scoring of immunohistochemical staining with Bmi-I and Snail antibody: no cytoplasmic positivity, very low positivity is <30\%, low positivity is $30-50 \%$, moderate positivity is $5 \mathrm{I}-80 \%$, and high positivity is $>80 \%$. 

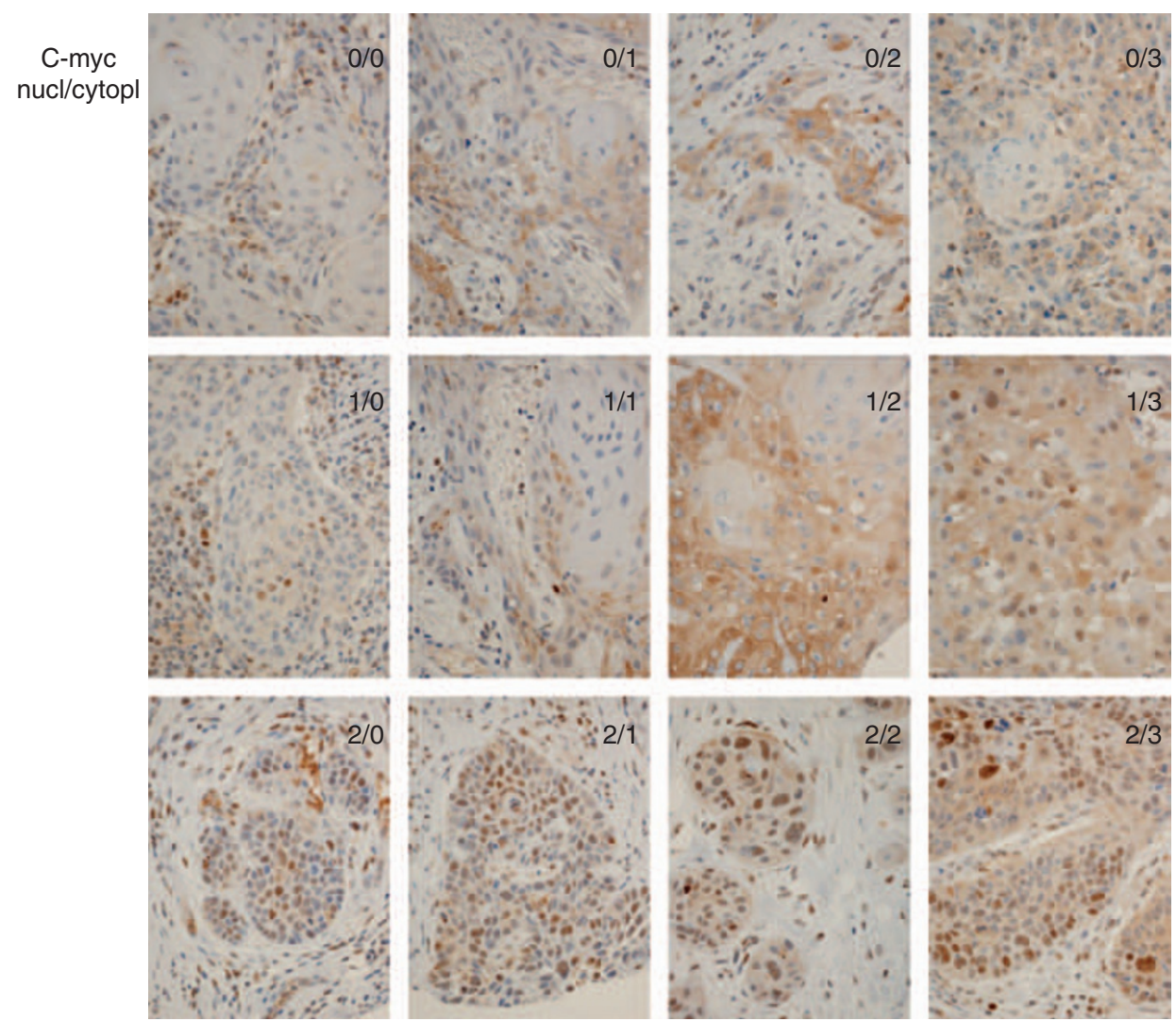

Figure 2 Scoring of c-myc immunopositivity in tongue carcinoma patients. Scoring was both nuclear and cytoplasmic (nucl/cytopl).

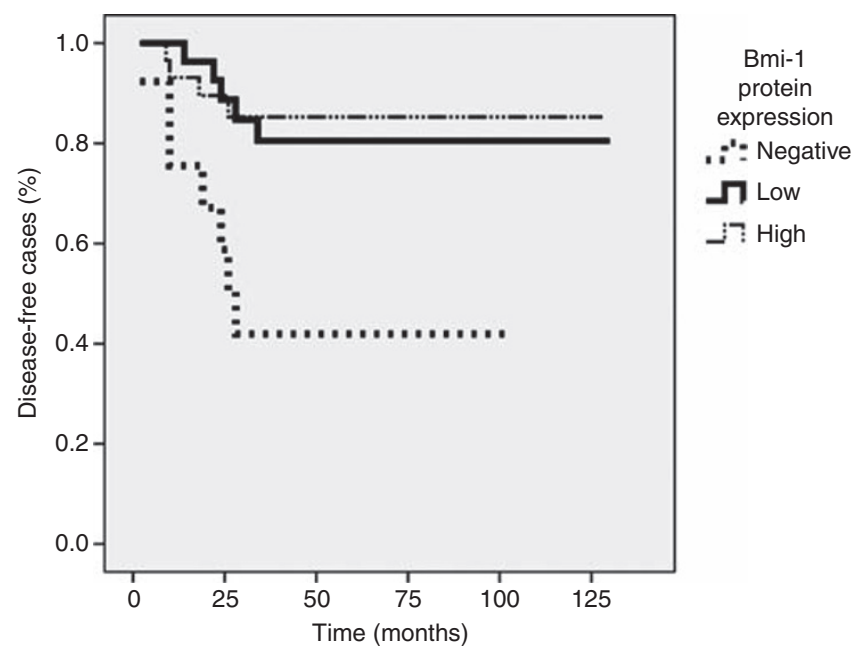

Figure 3 Kaplan-Meier graph of Bmi-I expression and disease-free survival.

No statistically significant difference in outcome was observed between patients with high and low Snail expression (log-rank test, $P=\mathrm{ns}$ ) (not shown). Similarly, tumours were grouped according to nuclear c-myc expression into negative (no expression) and positive categories.

No statistically significant difference in outcome was found between the c-myc negative and positive group (log-rank test, $P=\mathrm{ns})$. There was no correlation between cytoplasmic c-myc expression or Ki-67 staining and survival analyses, nor in outcome (not shown).

\section{Clinical and histopathological correlates}

The protein expression levels of all the markers (Table 1) were examined for correlations with clinical and histopathological parameters. These included degree of histological differentiation, tumour size, TNM classification, depth of invasion, and margin of resection. Snail expression was significantly lower in welldifferentiated tumours, whereas in poorly differentiated tumours, Snail expression was high (Fisher's exact test, $P=0.007$ ). Snail protein expression was also found to correlate with depth of invasion. In cases with the highest Snail score $(>80 \%$ positive tumour cells), the depth of invasion was greater ( $\chi^{2}$-test, $P=0.037)$. Finally, the prognostic significance of the abovementioned clinicopathological features was also evaluated. In brief, no other statistically significant correlations were found.

\section{DISCUSSION}

In this study, we examined the value of polycomb protein and oncogene Bmi-1, as well as proto-oncogene c-myc, transcription factor Snail, and proliferation marker Ki-67 expression, in a series of 73 oral tongue carcinoma patients in relation to clinical outcome.

We found a statistically significant correlation between lack of Bmi-1 immunoexpression and poor prognosis of OSCC patients. Interestingly, Bmi-1 overexpression has been earlier reported to be constantly present in a small series of patients $(N=10)$ with oral dysplastic and carcinoma tissue (Kang et al, 2007), but our research data consisted of 73 patients. Although high Bmi-1 overexpression is connected to poor prognosis in nasopharyngeal carcinoma (Song et al, 2006) and to non-small-cell lung cancer, breast carcinoma, and hepatocellular carcinoma (Vrzalikova et al, 2008), in our data, Bmi-1-negative tumours showed a correlation 
with poor prognosis. Several plausible explanations can be found for this. First, the roles of polycomb proteins are highly varied and depend on the composition of the polycomb repressive complex that Bmi-1 is a part of. The target genes and thus cellular functions such as migration, senescence, and proliferation effect vary considerably (Spivakov and Fisher, 2007). Furthermore, Bmi-1 expression has been identified as a prognostic factor only in certain types of cancer. For instance, in gliomas, Bmi-1 expression is prognostic in oligodendroglial tumours, in which its expression is abundant, whereas in the much more aggressive high-grade astrocytomas and glioblastomas, Bmi-1 expression is frequently very low and does not correlate with prognosis (Häyry et al, 2008). The apparent difference between the role of Bmi-1 in reported nasopharyngeal carcinoma cases (Song et al, 2006) and our material of OSSC may also be explained by the fact that nasopharyngeal carcinoma is a nonkeratinising type of carcinoma. Tongue carcinoma, on the other hand, is a keratinising SCC and its behaviour may be different from other cancer types.

C-myc expression in a microarray material has been lower in oral carcinomas, compared with laryngeal or pharyngeal primary carcinomas (Freier et al, 2003). This result may allude to the fact that oral carcinomas are different diseases compared with their counterparts in other anatomical sites. C-myc is presumed to take part in early oral carcinogenesis, but according to our study, nuclear c-myc immunoexpression did not show a significant correlation with prognosis, although a tendency was observed. C-myc mRNA downregulation has been shown to correlate with poor prognosis and progression of the disease (Vora et al, 2007). In this study, c-myc mRNA was not studied. In fact, Vora et al observed an inverse correlation between cytoplasmic c-myc protein expression and tumour stage. In our study, cytoplasmic c-myc expression did not show any correlation with clinical parameters. The discrepancy between these results may be caused by the small sample size $(n=19)$ used in the study by Vora et al (2007).

In this material, Ki-67 immunostaining did not provide any relevant prognostic information.

Snail has been shown to be active in OSSC and, concurrently, we found a positive expression in all our samples. Snail expression

\section{REFERENCES}

Al-Rajhi N, Khafaga Y, El-Husseiny J, Saleem M, Mourad W, Al-Otieschan A, Al-Amro A (2000) Early stage carcinoma of oral tongue: prognostic factors for local control and survival. Oral Oncol 36: 508-514

Arduino PG, Carrozzo M, Chiecchio A, Broccoletti R, Tirone F, Borra E, Bertolusso G, Gandolfo S (2008) Clinical and histopathologic independent prognostic factors in oral squamous cell carcinoma: a retrospective study of 334 cases. J Oral Maxillofac Surg 66: 1570-1579

Barnes L, Eveson JW, Reichart P, Sidransky D (2005) WHO: Pathology \& Genetics Head and Neck tumours. IARC Press: Lyon. 168

Batlle E, Sancho E, Franci C, Domínguez D, Monfar M, Baulida J, García De Herreros A (2000) The transcription factor Snail is a repressor of E-cadherin gene expression in epithelial tumour cells. Nat Cell Biol 2: $84-89$

Buduneli E, Vardar-Sengul S, Buduneli N, Wahlgren J, Sorsa T (2007) Matrix metalloproteinases -1, and Laminin-5 (gamma-2) chain immunolocalization in gingival tissue of endotoxin-induced periodontitisin rats: effects of low-dose doxycycline and alendronate. J Periodontol 78: $127-134$

Dimri GP, Martinez JL, Jacobs JJ, Keblusek P, Itahana K, Van Lohuizen M, Campisi J, Wazer DE, Band V (2002) The BMI-1oncogene induces telomerase activity and immortalizes human mammary epithelial cells. Cancer Res 62: 4736 - 4745

Dutton A, Woodman CB, Chukwuma MB, Last JI, Wei W, Vockerodt M, Baumforth KR, Flavell JR, Rowe M, Taylor AM, Young LS, Murray PG (2007) Bmi-1 is induced by Epstein-Barr virus oncogene LMP1 and regulates the exprssion of viral targer genes in Hodgkin lymphoma cells. Blood 109: 2597-2603 correlated with invasion depth in our material, suggesting a role in the primary invasiveness of OSCC. Indeed, tumour thickness has been found to correlate with metastasis, local recurrence, and survival (Po Wing Yuen et al, 2002). However, this chain of events did not directly reflect on the prognostic value of Snail expression, which was not statistically significant. However, there was a tendency for high Snail expression and poor prognosis. Although Snail expression has previously been connected to lymph node metastases and clinicopathological tumour stage in oesophageal SCC (Usami et al, 2008), in our data, the high Snail expression was correlated only to histopathological grading (well, moderate, or poor differentiation). According to many studies, the histological grading of OSCC does not correlate with clinical outcome (KeskiSäntti et al, 2007). This is in line with our results showing Snail expression correlating with tumour grade but not with prognosis. In OSCC, loss of the cadherin/catenin complex has been linked to the degree of differentiation but not to metastatic disease. This is in accordance with our findings, because Snail overexpression is linked to lowered cadherin/catenin expression (Mahomed et al, 2007; Zidar et al, 2008).

In conclusion, loss of Bmi-1 immunoexpression seems to correlate with clinical outcome of oral tongue SCC, in contrast to Snail or c-myc immunoexpression. Snail expression correlates with histological grading and depth of invasion. Our results suggest that loss of Bmi-1 might serve as a clinically relevant marker for poor prognosis in OSCC.

\section{ACKNOWLEDGEMENTS}

We thank Päivi Peltokangas, Tuire Koski, and Elina Aspiala for excellent technical assistance. This study was supported by the Sigrid Juselius Foundation, Finska Läkaresällskapet, Medicinska understödsföreningen Liv och Hälsa, The Finnish Female Dentists Association, N\&K Väreen säätiö, and the Finnish Cancer Foundation.

\section{Conflict of interest}

The authors declare no conflict of interest.
Ferlito A, Rinaldo A, Devaney KO, MacLennan K, Myers JN, Petruzzelli GJ, Shaha AR, Genden EM, Johnson JT, de Carvalho MB, Myers EN (2002b) Prognostic significance of microscopic and macroscopic extracapsular spread from metastatic tumor in the cervical lymph nodes. Oral Oncol 38: $747-751$

Ferlito A, Shaha AR, Rinaldo A (2002a) The incidence of lymph node micrometastases in patients pathologically staged N0 in cancer of oral cavity and oropharynx. Oral Oncol 38: $3-5$

Freier K, Bosch FX, Flechtenmacher C, Devens F, Benner A, Lichter P, Joos S, Hofele C (2003) Distinct site-specific oncoprotein overexpression in head and neck squamous cell carcinoma: a tissue microarray analysis. Anticancer Res 23: 3271-3277

Gil J, Kerai P, Lleonart M, Bernard D, Cigudosa JC, Peters G, Carnero A, Beach D (2005) Immortalization of primary human prostate epithelial cells by C-myc. Cancer Res 65: 2179-2185

Guney I, Wu S, Sedivy JM (2006) Reduced c-Myc signalling triggers telomerase-independent senescence by regulating Bmi-1 and p16(INK4a). Proc Natl Acad Sci USA 103: 3645-3650

Häyry V, Tynninen O, Haapasalo HK, Wölfer J, Paulus W, Hasselblatt M, Sariola H, Paetau A, Sarna S, Niemelä M, Wartiovaara K, Nupponen NN (2008) Stem cell protein BMI-1 is an independent marker for poor prognosis in oligodendroglial tumours. Neuropathol Appl Neurobiol 34: 555-563

Howell GM, Grandis JR (2005) Molecular mediators of metastasis in head and neck squamous cell carcinoma. Head Neck 27: 710-717

Jacobs JJ, Scheijen B, Vonchen JW, Kieboom K, Berns A, van Lohuizen M (1999) Bmi-1 collaborates with c-Myc in tumorigenesis by inhibiting c-Myc-induced apoptosis via INK4a/ARF. Genes Dev 13: 2678-2690 
Kang MK, Kim RH, Kim SJ, Yip FK, Shin KH, Dimri GP, Christensen R, Han T, Park NH (2007) Elevated BMI-1 expression is associated with dysplastic cell transformation during oral carcinogenesis and is required for cancer cell replication and survival. Br J Cancer 96: 126-133

Keski-Säntti H, Atula T, Hollmen J, Mäkitie A, Leivo I (2007) Predictive value of histopathologic parameters in early squamous cell carcinoma of oral tonque. Oral Oncol 43: 1007-1013

Keski-Säntti H, Atula T, Törnwall J, Koivunen P, Mäkitie A (2006) Elective neck treatment versus observation in patients with $\mathrm{T} 1 / \mathrm{T} 2$ squamous cell carcinoma of oral tongue. Oral Oncol 42: 96-101

Kim JH, Yoon SY, Jeong SH, Kim SY, Moon SK, Joo JH, Lee Y, Choe IS, Kim JW (2004) Overexpression of BMI-1 oncoprotein correlates with axillary lymph node metastases in invasive ductal breast cancer. Breast 13: 383

Koehn J, Krapfenbauer K, Huber S, Stein E, Sutter W, Watzinger F, Erovic BM, Thurnher D, Schindler T, Fountoulakis M, Turhani D (2008) Potential involvement of MYC- andp53-related pathways in tumorigenesis in human oral squamous cell carcinoma revealed by proteomic analysis. J Proteome Res 7: 3818-3829

Leung C, Lingbeek M, Shakhova O, Liu J, Tanger E, Saremaslani P, Van Lohuizen M, Marino S (2004) Bmil is essential for cerebellar development and is overexpressed in human medulloblastomas. Nature 428: $337-341$

Mahomed F, Altini M, Meer S (2007) Altered E-cadherin / $\beta$-catenin expression in oral squamous carcinoma with and without nodal metastases. Oral Dis 13: 386-392

Molofsky AV, He S, Bydon M, Morrison SJ, Pardal R (2005) BMI-1 promotes neural stem cell self-renewal and neural development but not mouse growth and survival by repressing the p16Ink4a and p19Arf senescence pathways. Genes Dev 19: 1432 - 1437

Pelengaris S, Khan M, Evan G (2002) C-myc: more than just a matter of life and death. Nat Rev Cancer 2: 764-776

Po Wing Yuen A, Lam KY, Lam LK, Ho CM, Wong A, Chow TL, Yuen WF, Wei WI (2002) Prognostic factors of clinically stage I and II oral tongue carcinoma-A comparative study of stage, thickness, shape, growth pattern, invasive front malignancy grading, Martinez-Gimeno score, and pathologic features. Head Neck 24: 513-520

Raaphorst FM, van Kemenade FJ, Fieret E, Hamer KM, Satijn DP, Otte AP, Meijer CJ (2000) Cutting edge: polycomb gene expression patterns reflect distinct $\mathrm{B}$ cell differentiation stages in human germinal centers. Immunol 164: 1-4
Silveira EJ, Godoy GP, Lins RD, Arruda Mde L, Ramos CC, Freitas Rde A, Queiroz LM (2007) Correlation of clinical, histological, and cytokeratin profiles of squamous cell carcinoma of the oral tongue with prognosis. Int J Surg Pathol 15: 376-383

Song LB, Zeng MS, Liao WT, Zhang L, Mo HY, Liu WL, Shao JY, Wu QL, Li MZ, Xia YF, Fu LW, Huang WL, Dimri GP, Band V, Zeng YX (2006) BMI-1 is a novel molecular marker of nasopharyngeal carcinoma progression and immortalizes primary human nasopharyngeal epithelial cells. Cancer Res 66: 6225-6232

Spivakov M, Fisher AG (2007) Epigenetic signatures of stem-cell identity. Nat Rev Genet 8: 263-271

Takkunen M, Ainola M, Vainionpää N, Grenman R, Patarroyo M, Garcia de Herreros A, Konttinen Y, Virtanen I (2008) Histochem Cell Biol 130: $509-525$

Takkunen M, Grenman R, Hukkanen M, Korhonen M, Garcia de Herreros A, Virtanen I (2006) Snail-dependent and -independent epithelialmesenchymal transition in oral squamous carcinoma cells. J Histochem Cytochem 54: $1263-1275$

Usami Y, Satake S, Nakayama F, Matsumoto M, Ohnuma K, Komori T, Semba S, Ito A (2008) Snail-associated epithelial-mesenchymal transition promotes oesophageal squamous cell carcinoma motility and progression. J Pathol 215: 330 -339

Vora HH, Shah NG, Trivedi TI, Goswami JV, Shukla SN, Shah PM (2007) Expression of C-myc mRNA in squamous cell carcinoma of the tongue. J Surg Oncol 95: 70-78

Vrzalikova K, Skarda J, Ehrmann J, Murray PG, Fridman E, Kopolovic J, Knizetova P, Hajduch M, Klein J, Kolek V, Radova L, Kolar Z (2008) Prognostic value of BMI-1 oncoprotein expression in NSCLC patients: a tissue microarray study. J Cancer Res Clin Oncol 134: $1037-1042$

Wang H, Pan K, Zhang HK, Weng DS, Zhou J, Li JJ, Huang W, Song HF, Chen MS, Xia JC (2008) Increased polycomb group oncogene BMI-1 expresion correlates with poor prognosis in hepatocellular carcinoma. J Cancer Res Clin Oncol 134: 535-541

Woolgar JA (2006) Histopathological prognosticators in oral and oropharyngeal squamous cell carcinoma. Rev Oral Oncol 42: $229-239$

Zidar N, Gale N, Kojc N, Volavsek M, Cardesa A, Alos L, Höfler H, Blechscmidt K, Becker KF (2008) Cadherin-catenin complex and transcription factor Snail-1 in spindle cell carcinoma of the head and neck. Virchows Arch 453: 267-274 